\title{
CO-FERMENTION OF MAIZE (Zea mays L.) AND AFRICAN BREAD FRUIT SEED (Treculia africana Dec'ne) FOR THE PRODUCTION OF IMPROVED PAP (OGI)
}

Oyeyipo, Funmilayo Mujidat; ${ }^{2}$ Taiwo, Olugbenga Samson and ${ }^{2}$ Obafemi, Yemisi Dorcas Department of Microbiology, Olabisi Onabanjo University, Ago-Iwoye, Ogun State, Nigeria. ${ }^{2}$ Department of Biological Sciences, Covenant University, Ota, Ogun State, Nigeria.

*Corresponding author: oyeyipo.funmilayo@oouagoiwoye.edu.ng

\section{ABSTRACT}

Cereals such as maize are generally having low essential amino acid contents which may cause protein malnutrition. The high essential amino acid in African breadfruit could make it suitable for supplementation of grains/cereals. The microbiological, sensory and nutritional evaluation of cofermented maize (70\%) /African breadfruit seed $(30 \%)$ was carried out. Characterization of isolate were by macroscopic, microscopic and biochemical tests. Standard Methods according to AOAC (1990) were used for proximate compositions and $\mathrm{pH}$ determination. Viscosity was measured using Rotational Viscometer. The $\mathrm{pH}$ of the co-fermented sample decreased from $6.2 \pm 0.01$ to $4.2 \pm 0.01$ Microbial isolates included Coryne bacterium spp., Lactobacillus spp., Escherichia coli, Staphylococcus aureus, Aspergillus niger and Saccharomyces cerevisae in fermenting samples. Escherichia coli was inhibited with increase in fermentation time. Higher microbial counts occurred fermentations. The viscosity of the co-fermented sample was $1.990 \pm 0.12$ pas $^{-1}$. Proximate composition shows that MOGI had lower crude protein content $(2.14 \pm 0.2)$ than $\mathrm{MABO}(9.83 \pm 0.3)$. In contrast, MOGI had higher crude carbohydrate $(82.12 \pm 0.1$ vs $72.59 \pm 0.2)$. Ash, moisture and lipid contents were not significantly different in both samples. Sensory evaluation revealed that MABO recorded higher scores $(7 \pm 0.02$ and $7 \pm 0.01)$ in taste and aroma as against ( $6 \pm 0.01$ and $6 \pm 0.02)$ fo MOGI. Although consumers accepted both samples, overall, MOGI was more acceptable. MABO flour kept well and retained their original viscosity after 27 days of storage at $\left(30 \pm 2^{\circ} \mathrm{C}\right)$. MABO gave dual advantage in that protein content was increased and enteropathogens were inhibited and is therefore recommended for consumption in areas where protein intake is inadequate and food safety is

Key words: Maize, African breadfruit, co-fermentation, nutrition, supplementation

Accepted Date: $29^{\text {th }}$ May 2018

\section{Introduction}

Maize (Zea mays) is native to tropical America where it has been grown for over 6,000 years. It is believed to have been introduced to Africa only ten years after the discovery of America in 1492, although both the period and the route of its introduction are uncertain. It was introduced to Nigeria probably in the $16^{\text {th }}$ century by the Portuguese (Osagie and Eka, 1998). In Nigeria, production of maize is common to all parts of the country, from North to South, with an estimated annual production of about 5.6 million tons (CBN, 1992). Maize is known by different vernacula names in Nigeria depending on the locality it is found such as, "Dawar Masara" or "Masara (Hausa); "Ogbado" or "Oka" (Ibo); "Apara" (Ibira); "Yangan" (Yoruba); "Ibokpot" (Efik). (Ibira); "Yangan" (Yorub); "Ibokpot" (Efik). Maize is processed into different traditional foods, varying from region to region, from one ethnic group to another. Fresh unripe maize can be roasted or boiled on the cob, and it is exceedingly popular in this form. Ripe dried grains are cooked with oil and condiments added and eaten as "adalu". Maize can be prepared into "Ogi" a fermented nonalcoholic starchy food; "Kenke" a traditional mea eaten in Ghana, or as popcorn which is eaten al over West Africa (Iwuoha and Eke, 1996).Cereal generally have low essential amino acid content which may cause protein malnutrition (Ashaye $e t$ al., 2000). Maize is generally low in lysine, methonine and tryptophan, therefore its nutritional value is greatly limited. This poor nutritiona quality of maize has been attributed to its high leucine content (Osagie and Eka, 1998). Direct amino acid supplementation has been shown to improve the nutritive value of corn based products (Ashaye et al., 2000). A major drawback of this approach is the fact that most maize products including "ogi" are produced in homes, by traditional methods. However, home processing methods do not include direct amino acid supplementation. This is because during preparation of ogi, most of the protein and almost all the fibre content are lost during the steeping process and to wash water. (Ashaye et al., 2000; Amusa et al., 2005)."Ogi” has been implicated in the etiology of protein malnutrition in children, as it is used as a major weaning food for children. (Naismith, 1973; Fashakin and Ogunsola, 1982 Oyarekua, 2011).Fermentation process has also been shown to deplete protein, lipid, fibre and as of the final product (Iwuoha and Eke, 1996) Therefore, there is a need for furthe supplementation in order to improve its nutritional value as food. Previous studies have shown that supplementation of "ogi" with legumes such as soya beans and cowpea resulted in products of high nutritive value (Marero et al., 1988; Amusa et al. 2005; Oyarekua, 2011). African breadfruit (Treculia africana) is a tree crop. The seed is popula Nigeria but underutilized, it has high protein and oil contents ( $23 \%$ and $11 \%$, respectively). The oil can be used for industrial purposes and also for human consumption due to its high food energy value. The high essential amino acid in African breadfruit could make it suitable to fortify grains/cereals (Oyeyipo, 2011). Microbil fermentation provides a way to food preservation, reduction in volume of materials to be transported, inhibition of microbial growth, improvement of appearance and taste of some foods and reduces the energy required for preparing food, ensures safer food products an enhancement of nutritive value (Oyarekua, 2011). There is little or no information on the cofermentation of cereals and African breadfrui seeds by traditional/laboratory processing methods of fermentation. Therefore, this study was aimed at formulating a cheap processing technique ( $\mathrm{co}^{-}$ fermentation) that can be practiced at household enriched foods with low-cost, biocompatible and locally available raw materials.

\section{MATERIALS AND METHODS}

Sources of maize and african breadfruit seeds

The maize (Zea mays) (yellow variety) and African breadfruit seeds (Trecuila africana) were purchased from mile 1 market in Port Harcourt, Rivers State, Nigeria.

\section{Preparation of nutritionally improved og}

There are slight variations from locality in the methods adopted for "ogi" production. However, the eventual product is the same anywhere it is made in Nigeria. The traditional preparation of "ogi" is a batch process carried out on a small scale. Winnowing and hand sorting of the grains are carried out to remove damaged or bad grains. Fo this study, "ogi" was produced using a modified method by Akingbala et al. (1981) with some modifications. Two hundred grams $(200 \mathrm{~g})$ of cleaned maize samples was soaked in a plastic bucket containing $300 \mathrm{ml}$ of water and another plastic bucket contained $140 \mathrm{~g}$ of maize and $60 \mathrm{~g}$ of plastic bucket contained 140g of maize and $60 \mathrm{~g}$ of steeped for $72 \mathrm{~h}$ at room temperature $\left(30 \pm 2^{\circ} \mathrm{C}\right)$. The water was then decanted and the steeped grain were wet milled using a clean blender (Model KM 910D; Kenwood Electronic, Hertfordshire, UK). It was then sieved using a fine mesh sieve $(300 \mu \mathrm{m})$. The filtered slurry was then allowed to sediment owed to sediment and passed through firthe fermentation for $24 \mathrm{~h}$ at $30 \pm 2^{\circ} \mathrm{C}$. The souring supernatant was decanted, and the slurry was collected using a sterile muslin cloth and hand squeezed to remove excess water. Samples were sun-dried and milled to obtain dry "ogi" powder (Figure 1) 
Maize/Maize + ABFS (70:30w/w)

Steep in $300 \mathrm{ml}$ water for $72 \mathrm{~h}$ (Primary Fermentation)

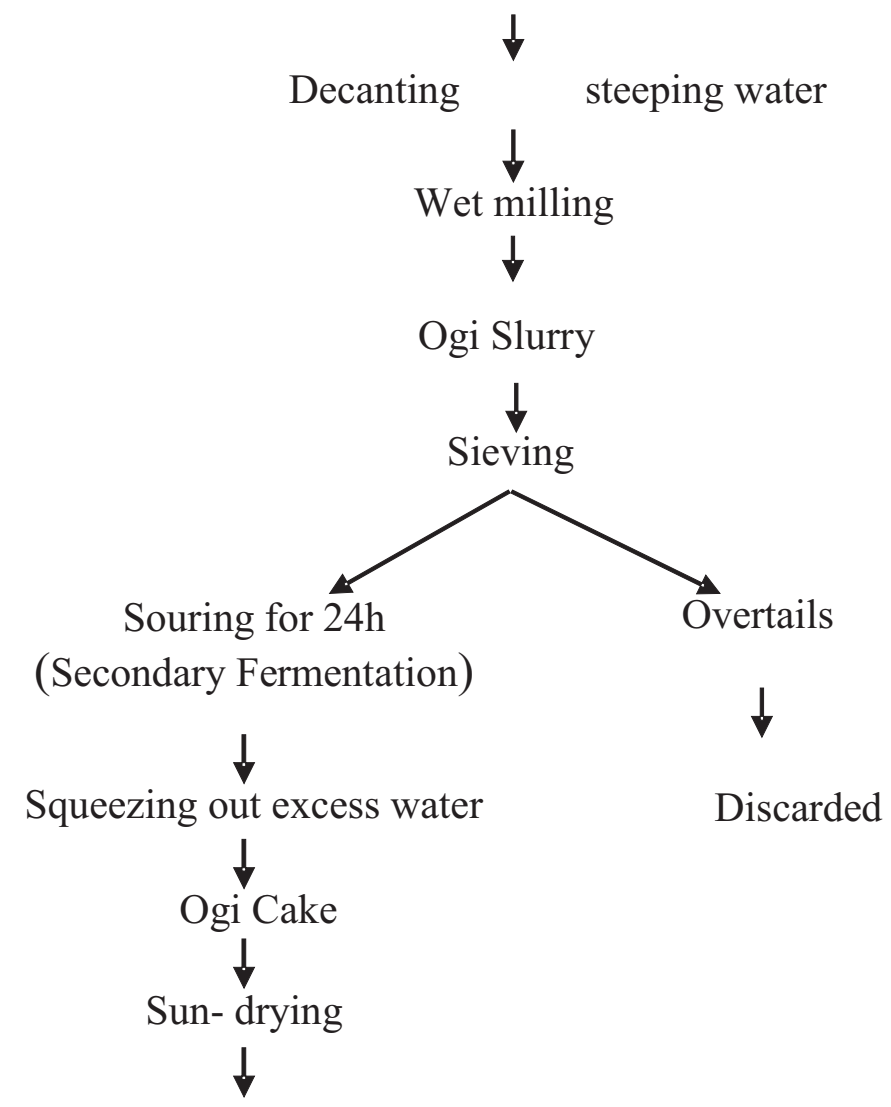

Dry milling of ogi Cake

Ogi/ABF-Ogi flour

Fig. 1: Flow Diagram for the Production of "Ogi" and ABF (African bread fruit) "Ogi"

\section{Microbial Evaluation of Steep Liquor}

Steep liquor (10ml portions) was aseptically collected every $24 \mathrm{~h}$ over the $72 \mathrm{~h}$ of primary fermentation and the $48 \mathrm{~h}$ of secondary fermentation and serially diluted with sterile distilled water (Oyarekua, 2011).

\section{Total Plate Count}

Aerobic plate counts were evaluated on plate count agar (PCA, Oxoid CM 325) using the pour plate method. Plates (in duplicate) were incubated at

\section{Coliform Counts}

These were done on MacConkey agar and incubated for $24 \mathrm{~h}$ at $37^{\circ} \mathrm{C}$. Confirmation of coliform was done on eosin methylene blue agar and incubation at $37^{\circ} \mathrm{C}$ for $24 \mathrm{~h}$. The growth of green metallic sheen colonies confirmed Coliforms.

\section{Staphylococcal Count}

Staphylococcal count was done using Mannitol salt agar, followed by incubation at $37^{\circ} \mathrm{C}$ for $24 \mathrm{~h}$

\section{Yeast and Mould Count}

Enumeration of yeasts and molds were done on Sabouraud Dextrose Agar (SDA) substituted with chloramphenicol. A $0.1 \mathrm{ml}$ of each sample was dropped in sterile agar plates and evenly spread using a glass spreader. The inoculated plates were incubated at room temperature $\left(28 \pm 2^{\circ} \mathrm{C}\right)$ for 5 days. The isolates were identified using conventional microbiology methods, i.e. morphology.

Identification and Characterization of Isolates All the isolated organisms were identified using conventional microbiological methods. For bacteria, the standard tests used for characterization of the isolates were microscopic examination, biochemical tests and sugar fermentation Identification was also based on comparison of characteristics of the isolates with comparison of chactistics of the isolates with Bacteriology, 8th edition, 1974. Fungi were identified using their morphology.

Physico-chemical analyses of maize ogi and maize-African breadfruit ogi

\section{Determination of $\mathrm{pH}$}

The $\mathrm{pH}$ of the fermenting samples was determined according to the method of AOAC (1990). Ten gram of sample was mixed in $100 \mathrm{ml}$ of $\mathrm{CO}_{2}$ - free distilled water. The mixture was allowed to stand for $15 \mathrm{~min}$ shaken at $5 \mathrm{~min}$ interval and filtered with Whatman No. 14 filter paper. The $\mathrm{pH}$ of the filtrate was measured in duplicate using a $\mathrm{pH}$ meter (Model HM-305, Tokyo, Japan)

Determination of total titratable acidity (TTA) Ten millilitre aliquots of the samples were pipetted and titrated against $0.1 \mathrm{M} \mathrm{NaOH}$ solution to phenolphthalein end point and the acidity was calculated as g lactic acid /100\%(AOAC, 1990).

\section{Determination of viscosity}

Viscosity procedure: Simple empirical measurement for consistency of each gruel was determined using Botswick Consistometer. (Laomat CEDEX). Four to $18 \%$ (on dry matter basis weight 'ogi' gruel cake: water) were mixed and stirred constantly on hot plate $80^{\circ} \mathrm{C}$. At the first appearance of first bubble, cooking was timed to 5 minutes after which it was cooled to $45^{\circ} \mathrm{C}$. The first compartment was filled with $100 \mathrm{ml}$ of each sample (maize ogi and maize-aAfrica breadfruit ogi). At time $=0$, the trigger was pressed to release the the gate of the first compartment to allow gruel flow by gravity to the second conpartment. The distance the gruel covered in 30seconds was measured in millimeters as the Bostwick Consistency reading (i.e flow in $\mathrm{mm} / 30$ seconds). Dry matter of gruel was determined according to AOAC (1990).

Viscosity measurement was determined using Haake VT500 viscometer with coaxial gruel spindle. The computerized viscometer was operated to record the viscosity of gruel for 10minutes shear SV-Din spindle at 83.21 sec(64.5rpm), gruel temperature $=45^{\circ} \mathrm{C}$. Readings were taken in Pascal per seconds $\left(\mathrm{Pas}^{-1}\right)$ after 10 minutes of spindle rotation when they became stable. The dry matter values were compared with consistency and viscosity measurements (Oyarekua, 2011; Onasoga et al., 2014).

\section{Proximate analyses}

The carbohydrate, moisture content, lipid and percentage ash compositions of maize ogi and maize-African breadfruit ogi were analyzed using standard methods (Osborne and Voogt, 1978 AOAC, 1990). Crude protein was determined using kjeldahl method, where nitrogen percentage was multiplied by a factor of 6.25 to obtain crude protein (AOAC, 1990).

Sensory evaluation of maize ogi and maizeAfrican breadfruit ogi

African breadfruit ogi Ten-man panels (habitual consumer of "ogi") were used for this study. The products (maize ogi and maize-African breadfruit ogi) were reconstituted into meal and evaluated organoleptically. The porridge sample were assessed for colour, taste, odour, consistency and overall acceptability using a 
nine (9) point hedonic scale on basis of their acceptability with $1=$ disliked extremely $9=$ like extremely (Modu and Milala, 2004; Onasoga et al., 2014)

\section{Statistical analysis}

Data obtained were subjected to mean and standard deviations using Statistical Package for Social Sciences (SPSS) version 16.0. Significant means $(p$ $<0.5)$ were separated using Duncan multiple range test.

\section{RESULTS}

pH and titratable acidity (TTA) during steeping There was a gradual decrease in the $\mathrm{pH}$ values of MOGI from $6.3 \pm 0.03$ to $6.0 \pm 0.03$ at 0 and $24 \mathrm{~h}$ of steeping, at $72 \mathrm{~h}$ the $\mathrm{pH}$ decreased to $4.9 \pm 0.04$. The $\mathrm{pH}$ of MABO also showed similar pattern of decrease, from $6.2 \pm 0.01$ to $6.0 \pm 0.01$ at 0 and $24 \mathrm{~h}$ decrease, from $6.2 \pm 0.01$ to $6.0 \pm 0.01$ at 0 and $24 \mathrm{~h}$, and $4.7 \pm 0.01$ at $72 \mathrm{~h}$. Titratable acidity (TTA)
increased as $\mathrm{pH}$ decreased, for MOGI $(0.07 \pm 005$ to increased as $\mathrm{pH}$ decreased, for $\mathrm{MOGI}(0.07 \pm 005$ to $\mathrm{MABO}$ recorded higher viscosity value $(1.990 \pm 0.16)$ than MOGI (1.890 \pm 0.12$)$ (Table 1)

Table 1: pH,Titratable acidity and Viscosity values of MOGI and MABO

\begin{tabular}{|c|c|c|c|c|c|c|}
\hline \multicolumn{7}{|c|}{ Fermentation time (Hour) } \\
\hline $\begin{array}{l}\text { Sample } \\
\text { codes }\end{array}$ & Parameter & 0 & 24 & 48 & 72 & $\mathrm{~V}\left(\mathrm{pas}^{-1}\right)$ \\
\hline MOGI & $\mathrm{pH}$ & $6.3 \pm 0.03$ & $6.0 \pm 0.03$ & $5.1 \pm 0.01$ & $4.9 \pm 0.04$ & $1.890 \pm 0.12$ \\
\hline TTA & TTA & $0.07 \pm 0.05$ & $0.14 \pm 0.03$ & $0.72 \pm 0.04$ & $0.25 \pm 0.02$ & \\
\hline MABO & $\mathrm{pH}$ & $6.2 \pm 0.01$ & $6.0 \pm 0.01$ & $5.0 \pm 0.02$ & $4.7 \pm 0.01$ & $1.990 \pm 0.16$ \\
\hline TTA & TTA & $0.07 \pm 0.05$ & $0.09 \pm 0.02$ & $0.18 \pm 0.03$ & $0.14 \pm 0.02$ & \\
\hline
\end{tabular}

Key: Values are mean \pm standard deviation of two replicates $(n=2)$. MOGI $=$ Maize Ogi; MABO=MaizeAfrican Breadfruit Ogi; V= Viscosity, pas $^{-1}=$ Pascal per second.

Microbial quality of Maize ogi and MaizeAfrican Breadfruit ogi

Tables 2-5 show the occurrence of microbial isolates (bacteria and fungi) from fermenting samples during primary and secondary fermentations of MOGI and MABO. Lactobacillus species were the major isolates in both samples, occurring throughout the fermentation time ( 0 to 72 $\mathrm{h}$ for primary fermentation, and $0-24 \mathrm{~h}$ for secondary fermentation). Escherichia coli was isolated at time 0 and $24 \mathrm{~h}$ during the primary fermentations of MOGI and MABO, however, it was not isolated after $24 \mathrm{~h}$ of primary fermentations (tables 2 and 3). Similarly, Clostridium bifermentans was iso at the Clostridium bifermentans was isolated at he inial stage $(0 \mathrm{~h})$ of prinary fermentation of MABO but was isolated with further fermentation (table 3). Also, Staphylococcus aureus was isolated during initial stages $(0-24 \mathrm{~h})$ of primary and secondary fermentations (except at the secondary fermentation stage of $\mathrm{MABO}$ ), but its growth was inhibited as fermentation progressed (tables 2, 3 and 4). Saccharomyces cerevisiae was consistently isolated in both samples during the primary and secondary fermentation stages, however, Aspergillus niger occurred at the initial stages $(0 \mathrm{~h})$ in both samples during the primary fermentations but with further fermentation its growth was no observed. Tables 6 and 7 shows the microbial counts (bacterial and fungal, respectively) during the primary and secondary fermentations of MOG and MABO. MOGI recorded lower bacterial and fungal counts $(1.8 \times 109$ and $1.4 \times 101)$ compared to MABO (1.9x109 and 1.2x102) during the primary ferme (1.9x $1.8 \times 109$ and $1.2 \times 102)$ dy the secondary fermention, observed durin the secondary fermentation, with MABO recording higher microbial counts $(3.8 \times 106$ an $3.4 \times 102)$ compared with $(3.5 \times 106$ and $3.0 \times 102)$ fo MOGI
Table 2: Occur rence of Microorganisms during primary fermentation of Maize "ogi" Fermentation time (hours)

Microbial isolates

Clostridium bifermentans

Corynebacteriumspp.

Lactobacillus fermentum

Lactobacillus plantarum

Escherichia coli

Staphylococcus aureus

Aspergillusniger

Mucormucedo

Penicilliumspp.

Rhizopusstolonifer

Saccharomyces cerevisiae

\begin{tabular}{lllll}
\cline { 5 - 5 } \cline { 5 - 5 } \cline { 5 - 5 } \cline { 5 - 5 } & & 24 & 48 & 72 \\
+ & - & & - & - \\
+ & + & & + & + \\
+ & + & & + & + \\
+ & + & & + & + \\
+ & + & & - & - \\
+ & - & & - & - \\
+ & - & & - & - \\
- & - & & - & - \\
- & - & & - & - \\
- & - & & - \\
+ & + & + & +
\end{tabular}

Key: $+=$ Isolated, $-=$ Not isolated

Table 3: Occurrence of Microorganisms during primary fermentation of Maize-African bread fruit "ogi"

\begin{tabular}{lcccc}
\hline Fermentation Time (hour) & \multicolumn{4}{l}{} \\
\cline { 2 - 5 } Microbial Isolates & 0 & 24 & 48 & 72 \\
\hline Clostridium bifermentans & + & - & - & - \\
Corynebacteriumspp. & + & + & - & - \\
Lactobacillus fermentum & + & + & + & + \\
Lactobacillus plantarum & + & + & + & + \\
Escherichia coli & + & + & - & - \\
Staphylococcus aureus & + & + & - & - \\
Aspergillusniger & + & - & - & - \\
Mucormucedo & - & - & - & - \\
Penicilliumspp. & + & - & - & - \\
Rhizopusstolonifer & - & - & - & - \\
Saccharomyces cerevisiae & + & + & + & + \\
\hline
\end{tabular}

Key; + = Isolated, - = Not isolated 
Table 4: Occurrence of Microorganisms during secondary fermentation of Maize ogi

Fermentation time (hours)

Microbial Isolates

Clostridium bifermentan

Corynebacteriumspp.

Lactobacillus fermentum

Lactobacillus plantarum

Escherichia coli

Staphylococcus aureus

Aspergillusniger

Mucormucedo

Penicilliumspp.

Rhizopusstolonifer

Saccharomyces cerevisiae

Key: + = Isolated, - = Not isolated

Table 5: Occurrence of Microorganisms during secondary fermentation of Maize-African Bread fruit ogi

Fermentation time (hours)

Microbial Isolates

\begin{tabular}{lll}
\cline { 2 - 3 } & 24 & 48 \\
\hline- & - & - \\
- & - & - \\
+ & + & + \\
+ & + & + \\
- & - & - \\
- & - & - \\
- & - & - \\
- & - & - \\
- & - & - \\
- & - & - \\
+ & + & + \\
\hline
\end{tabular}

Clostridium bifermentans

Corynebacteriumspp.

Lactobacillus fermentum

Lactobacillus plantarum

Escherichia coli

Staphylococcus aureus

Mucormucedo

Penicilliumspp.

Rhizopusstolonifer

Saccharomyces cerevisiae

\begin{tabular}{lll}
\hline 0 & 24 & 48 \\
- & - & - \\
- & - & - \\
+ & + & + \\
+ & + & + \\
- & - & - \\
+ & - & - \\
- & - & - \\
- & - & - \\
- & - & - \\
- & - & - \\
+ & + & +
\end{tabular}

Key. + = Isolated; $-=$ Not isolated

Table 6: Total Bacterial and Fungal counts (log cfu/ml) during primary fermentation

Bacteria

Fungi

Time (hours) MOGI

MABO

MOGI

MABO

$\begin{array}{ll}0 & 3.0 \times 10^{9}\end{array}$

$3.4 \times 10^{9}$

$1.0 \times 10^{2}$

$24 \quad 4.1 \times 10^{9}$

$4.3 \times 10^{9}$

$2.5 \times 10^{1}$

$1.5 \times 10^{2}$

$48 \quad 2.6 \times 10^{9}$

$2.8 \times 10^{9}$

$1.5 \times 10^{1}$

$2.9 \times 10^{1}$

$72 \quad 1.8 \times 10^{9}$

$1.9 \times 10^{9}$

$1.4 \times 10^{1}$

Key: MOGI = Maize ogi; MABO = maize- African breadfruit ogi; $\mathrm{cfu}=$ Colony forming unit
Table 7: Total Bacterial and Fungal counts $(\log \mathrm{cfu} / \mathrm{ml})$ during secondary fermentation Bacteria

Time (hours)

48

\begin{tabular}{|c|c|c|c|}
\hline \multicolumn{2}{|c|}{ Fung1 } & \multirow[b]{2}{*}{ MOGI } & \multirow[b]{2}{*}{ MABO } \\
\hline MOGI & MABO & & \\
\hline $1.2 \times 10^{6}$ & $1.7 \times 10^{6}$ & $0.4 \times 10^{2}$ & $0.6 \times 10^{2}$ \\
\hline $2.6 \times 10^{6}$ & $2.8 \times 10^{6}$ & $2.1 \times 10^{2}$ & $2.5 \times 10^{2}$ \\
\hline $3.5 \times 10^{6}$ & $3.8 \times 10^{6}$ & $3.0 \times 10^{2}$ & $3.4 \times 10^{2}$ \\
\hline
\end{tabular}

Key: MOGI = Maize ogi; MABO = African breadfruit ogi; cfu=Colony forming unit

Proximate composition

Table 8 shows the proximate composition of MOGI and MABO. MOGI had lower protein (2.14 \pm 0.2$)$ compared to MABO $(9.83 \pm 0.3)$. In contrast, $\mathrm{MOGl}$ recorded higher carbohydrate $(82.12 \pm 0.1)$ than $\mathrm{MABO}(72.59 \pm 0.2)$. The moisture and ash content $(10.22 \pm 0.3$ and $2.09 \pm 0.03)$ of MOGI were lower than MABO (10.49 \pm 0.2 and 2.78 \pm 0.01$)$. MABO recorded higher lipid (6.31 \pm 0.2$)$ content as against $5.43 \pm 0.3$, for

Table 8: Proximate composition of MOGI and MABO

\begin{tabular}{clllll} 
Samples code & Moisture & Ash & Protein & Lipid & Carbohydrate \\
\hline MOGI & $10.22 \pm 0.3$ & $2.09 \pm 0.03$ & $2.14 \pm 0.2$ & $5.43 \pm 0.3$ & $82.12 \pm 0.1$ \\
MABO & $10.49 \pm 0.2$ & $2.78 \pm 0.01$ & $9.83 \pm 0.3$ & $6.31 \pm 0.2$ & $72.59 \pm 0.2$ \\
\hline
\end{tabular}

Key: Values are mean \pm standard deviation of 2 replicates $(\mathrm{n}=2)$, MOGI $=$ Maize $\mathrm{O}$

$\mathrm{MABO}=$ Maize-African Breadfruit Ogi.

Sensory evaluation

Mize ogi had higher scores in visual appearance, consistency and overall acceptability $(8 \pm 0.3,8 \pm 0.01$ and $7 \pm 0.02)$ compare with $(7 \pm 0.1,7 \pm 0.03$ and $6 \pm 0.02)$ for $\mathrm{MABO}$, whereas, MABO recorded higher scores in taste and aroma $(7 \pm 0.02$ and $7 \pm 0.01)$ a

\begin{tabular}{cccccc}
\multicolumn{2}{l}{ Table 9: Sensory evaluation of MOGI and MABO } & & \\
Sample & $\begin{array}{l}\text { Visual } \\
\text { appearance }\end{array}$ & Taste & Aroma & Consistency & $\begin{array}{l}\text { Overall } \\
\text { acceptability }\end{array}$ \\
MOGI & $8 \pm 0.03$ & $6 \pm 0.01$ & $6 \pm 0.02$ & $8 \pm 0.01$ & $7 \pm 0.02$ \\
MABO & $7 \pm 0.01$ & $7 \pm 0.02$ & $7 \pm 0.01$ & $7 \pm 0.03$ & $6 \pm 0.02$
\end{tabular}

Key: Values are mean \pm standard deviation of 10 scores from 10 member panel. MOGI $=$ Maize Ogi; MABO=Maize-Afric an Breadfruit Ogi. 


\section{DISCUSSION}

Microorganism (bacteria, yeasts and moulds) may not appear to play any significant role in fermentation processes; however microbial interactions of mixed-bacterial, fungal-yeasts and interactions of mixe indigenous the nutritional, safety and sensory characteristics of the end product. The development of lactic acid bacteria is also stimulated by the presence of yeasts which provide soluble nitrogen compounds and factors like B- vitamin (Amusa et al., 2005; Oyerekua, 2011). The significant decrease in $\mathrm{pH}$ of fermented samples could be due to the degradation of starch in the substrates by microorganisms (bacteria and fungi) with the production of various organic acids, consequently lowering the $\mathrm{pH}$ of the substrates. The comparative lower pH of the cofermented mixture may be attributed to the availability of more nutrients from the African breadfruit seed that can enhance microbial metabolic activities (Oyerekua, 2011). In contrast, titratable acidity showed a gradual increase. The increase in titratable acidity values may be due to the activities of acid producing microorganisms such as Lactobacillus spp. (Akinrele, 1970; Banigo and Muller, 1972; Oyerekua, 2011; Onasoga, 2014). As the microbial flora multiply, the lowering of $\mathrm{pH}$ and increase in titratable acidity in the general fermentation environment create conditions favorable for some organisms such as lactic acid bacteria and yeasts which can tolerate the acidic environment while inhibiting the growth of others such as the enteric organisms, which is desirable in fermented food products especially in the extension of shelf-life of the product, probiotics and impartation of characteristic aroma to the food product(Oyeyipo, 2011; Onasoga et al., 2014).

Co-fermentation did not significantly affect the viscosity of maize-African breadfruit ogi in this study. The higher value of lipid in co-fermented sample (MABO) compared to their nonsupplemented analogue (MOGI) might be responsible for higher viscosity values of cofermented mixtures because lipids do not absorb water in gruel preparations (Oyeyipo, 2011; Oyerekua 2011). Viscosity reduction is due mainly to amylolytic activity. This is corroborated by the to anylycic activity. This is comorated by the not reduce the viscosity of $60 \%$ cereal and $40 \%$ legumes.
The supplementation of maize ogi with African bread fruit did not result in a significant difference in microbial types. Perhaps due to the facts that the bacteria, yeasts and moulds in this study are known contaminants in cereals(Oyerekun, 2011) and the dehulling process dehulling process of the African breadfruit prior to co-fermentation with maize, which might have drastically reduced its microbial burden (Onasoga, 2011; Oyeyipo, 2011). Lactobacillus spp. Corynebacterium spp., Saccharomyces cerevisiae were the predominant organisms isolated from all samples. The isolation of these organisms is in agreement with earlier reports (Amusa et al., 2005; Oyarekua, 2011). The presence of both lactic acid bacteria (Lactobacillus spp. and Corynebacteriumspp.) and yeast (Saccharomyces Coryebacteriumsp.) and yeast (Sacharomyces cerevisae) are very significant. The lactics degrade starch in the verstan sof various organic acids and lowers the $\mathrm{pH}$. The yeas produces a variety of aldehyde and esters that are responsible for the characteristic desirable taste an aroma of fermented products (Oyarekua, 2011 Oyeyipo, 2012; Onasoga et al., 2014). The inhibition of enteropathogens in both maize ogi and maize-African breadfruit ogi confirms the probiotic effect of lactic acid bacteria in fermented foods (Amusa et al.. 2005; Onasoga, 2014)

The subsequent disappearance of moulds/yeasts could probably be due to the low oxygen tension in the fermenting medium. This is because the amount of available oxygen to eukaryotic cells is a critica factor in determining their overall cellula metabolism. As most eukaryotic fungi are generally considered obligate aerobes, oxygen availability during fungi metabolism may play critical role in their multiplication (Oyeyipo, 2011). Saccharomyces and Candida species have been reported in spontaneous lactic acid fermentation of coreals (Oyareku, 2011). Tot plate counts were higher in maize-African bread truit ogi maize ogi counts, perhaps due to the solubiliza ar progicounts, perhaps due to the solubilization of protein contained in the African breadfruit seed which might have buffered the acid produced, thus giving less inhibitory effect. Total plate counts showed both homofermentative and heterofermentative bacteria. This is in agreement with the findings of Oyarekua (2011).

Sensory evaluation of maize-ogi and maizeAfrican breadfruit ogi revealed that maize ogi recorded higher in consistency and visual appearance, while maize-African breadfruit ogi recorded higher scores in taste and aroma. Rating on visual appearance demonstrated that supplementation of ogi with African breadfruit slightly affected the colour. The prepared maizes fric affected the colour. The prepared maizeAfrican breadfrut ogi had better perceptible arom than prepared mize ogi sample. The prepare maize-African breadfruit ogi was described to have a fruity-acid aroma while prepared maize ogi was described as having an acid aroma. The differences in aroma ratings between prepared maize ogi an prepared maize-African breadfruit ogi may be attributed to the processes applied. The acid aroma may be attributed to the organic acids produced during the fermentation process (Oyeyipo, 2011). Prepared maize-African breadfruit ogi had more perceptible fruity-acid flavour while prepared maize ogi sample had acid flavour. These results maize ogi sample had acid flavour. These results
logically follow the observations made in the logically follow the observations made in the
corresponding aroma attribute. Although consumers accepted the supplemented product, maize ogi was more acceptable. This may be attributed to the fact that consumers are more familiar with maize and its products (Adelekan and Oyewole, 2010). Proximate analyses revealed that ash and moisture contents of maize ogi and maizeAfrican breadfruit ogi were comparable. The carbohydrate content of maize ogi was higher than that of maize-African breadfruit ogi sample. This agrees with the observations of Oyarekua (2011) and Modu and Milala (2004); that the addition of legumes decreased the carbohydrate of cereal based traditional foods. In contrast, higher lipid was observed in maize-African breadfruit ogi than maize ogi samples, the high lipid content is attributable to the higher lipid content of African breadfruit seed compared to maize seed (Oyeyipo, 2011; Onasoga, 2014). Similarly, crude prote 2011; Onas content was higher in maize-African breadfruit ogi than in maize ogi sample. This is due to the
supplementation of maize with African breadfruit seed. The significant increase recorded in protein level of maize-African breadfruit ogi is consistent with earlier reports (Modu and Milala, 2004; Oyarekua, 2009). A good supplementa relationship thus exists between maize and African breadfruit seed in this study. MABO gave a dual advante in that proten cont enteropathogens were inhibited and is therefore protein intake is inadequate and food safety is an issue

\section{REFERENCES}

Adelekan, A. O. and Oyewole, O. B. 2010 Production of Ogi from Germinated Sorghum Supplemented with Soybeans. African Journal of Biotechnology. 9 (42):7114-7121.

Akingbala J. O., Rooney, L. A. and Faubion, J. M 1981. A Laboratory Procedure for the Preparation of Ogi, Nigerian Fermented Food. Journal of Food Science. 46:15231526.

Akinrele, I. A. 1970. Fermentation Studies on Maize during the Preparation of traditional African starch-cake food. Journal of $t h e$ Science of Food and Agriculture. 21:61Science
625.

Amusa, N.A., Ashaye, O. A. and Oladapo, M. O. 2005.Microbiological Quality of Ogi and Soy-Ogi (A Nigerian fermented Cereal Porridge) widely Consumed and Notable Weaning food in Southern Nigeria. Journal of Agriculture, Food and Environment. 3(2):81-83.

A.O.A.C. 1990.Official Methods of Analysis of the Association of Official Analytical Chemists. $15^{\text {th }}$ Edi. AOAC Arlington Virginia.

Ashaye, O. A., Fasoyiro, S. B. and Kehinde, R. O 2000.Effect of Processing on the Chemical and Sensory Quality of Ogi Fortified with full fat cowpea flour. Journal of Agricultural Research. 1:115-123.

Barnett, H. L. and Hunter, B. B. 1972. Illustrated Genera of Imperfect Fungi. $3^{\text {rd }}$ ed. Burgress, Minnesota.

Banigo, E. I. O. and Muller, H. C. 1972 Manufacture of Ogi (A Nigerian Fermented Cereal Porridge): Comparative Evaluation of Corn, Sorghum and Millet. Journal of Food Science and Technology. 5:217-221.

Central Bank of Nigeria (CBN) 1992. Annual Report and Statement of Accounts. Central Bank of Nigeria, Lagos. pp. 78

Fashakin, J.B. and Ogunsola, F.1982. The utilization of local foods in fermentation of 
weaning foods. Tropical Paediatrics. 28:93-96.

Iwuoha, C. I. and Eke, O. S. 1996. Nigerian indigenous fermented foods: their traditional process operation, inherent problems, improvement and status. Food Research International.29:527-540.

Marero, L. M., Payumo, E. M., Librando, E.C.,Lainez, W. N., Gopez, M. D. and Homma, S. 1989.Technology of weaning Food formulations prepared from germinated cereal and legumes. Journal of Food Science .53(3):1391-1395.

Modu, S.H.Z. and Milala, M. A. 2004. Effect of supplementation of ogi, a pearl millet based Nigerian weaning food, with cowpea, on ine on protein digestibility. Journal of Biological protein digestibility. Journal of Biological
Sciences. 4(5): 654-657. Sciences. 4(5): 654-657.

Naismith, D.J. 1973. Kwashiokor in Western Nigeria: a study of traditional weaning foods with Particular Respect to Energy and Linoleic acid. Journal of Nutrition, 80: 567576.

Njoku, H.O., Ibe, S. N., Odu, N. N. and Oyeyipo, O. O. (2013).Processing and characteristics of African breadfruit tempe-fortified lafun. Nature and Science. 11 (1): 116-120.

Osborne, D. R. and Voogt, P. 1978. The Analysis of Nutrients in Foods. Academic press, London, pp.113-16.

Osagie, A. U. and Eka, O. U. 1998. Nutritional Quality of Plant Foods. Post Harvest Research Unit, University of Benin, Benin. pp. 34-41.

Onasoga, M. F., Ayodele, D. O. and Oyeyipo O. O. (2014). Chemical changes during the fortification of cassava meal (Gari) with African breadfruit (Treculiaafricana) Residue.Journal of Applied Sciences and Residue.Journal of Applied Sciences and
Environmental Management. 18 (3): 506Environmental Management. 18 (3): 506-
512. Oyarekua, M.A. 2011. Evaluation of the nutritional and microbiological ogriculture and Biology Journal of North America. 2(10): 61-73.

Oyeyipo, O.O. 2011.Studies on Lafun Fortified with African breadfruit Tempe flour. MSc thesis, University of Port Harcourt, Nigeria.

Oyeyipo, O. O., Ibe, S. N. and Njoku, H. O. (2012). Evaluation of lafun fortified with African breadfruit tempe. A paper presented at the proceedings of the $16^{\text {th }}$ Annual world congress of food science and technology, Brazil.

Steel, R.G.D. and Torries, J. H. 1980.Principles and Procedures of Statistics, McGraw-Hill Book Company Inc. New York, USA.

Uwaegbute, A .C. and Nnanyelugo, D. O. 1989 Towards improving the nutritional value of traditional weaning foods. In: Fashakin, J. B(ed.) Proceedings of the workshop on present knowledge on weaning Foods in Nigeria. Federal Institute for Industria Research, Oshodi, Lagos, 1989:63-85.

Umoh, V. and Fields, M. L. 1981.Fermentation of corn for Nigerian Agidi. Journal of Food Science 46:903-905. 